\title{
Performance appraisal as antecedents of job satisfaction among employees in a selected public institution of higher learning
}

Siti Mariam Abdullah ${ }^{1 *}$, Nur Fatihah Abdullah Bandar ${ }^{2}$, Rusli Ahmad ${ }^{3}, H_{\text {Helmi Sumilan }}^{4}$, and Ahmad Sopian Shminan $^{5}$

${ }^{1,2,3,4,5}$ Universiti Malaysia Sarawak (UNIMAS)

\begin{abstract}
Performance appraisal (PA) is an important activity in any organisation. Employers have the responsibility of evaluating the work performance of each and every employee. In acknowledgement of this, most organizations persist in conducting performance appraisals despite numerous problems and constraints. This research attempts to determine the influence of performance appraisal as antecedents of job satisfaction among employees in a selected public institution of higher learning in Sarawak, East Malaysia. Quantitative methodology using an adapted questionnaire with statistical tests like Pearson Correlation Coefficient and Multiple Linear Regression (Stepwise) were utilised to analyse the data. The findings indicated that the strengths, weaknesses, opportunities and threats of PA have a positive and significant relationship with job satisfaction. Results also revealed that the strengths of PA is one of significant factors contributing to job satisfaction among employee on the practice of performance appraisal system.
\end{abstract}

Keywords: Job Satisfaction, Performance Appraisal, Public institutions, SWOT

\section{INTRODUCTION}

Performance Appraisal (PA) is commonly used as a means to determine the performance of employees in organisations. It is significanthuman resource management practice everywhere and significantly contribute to sustains the organisational survival (Ahmad, 2019). For public organisations in Malaysia, it is conducted annually in which evaluators, at the supervisory level will make decisions based on prescribed performance indicators of each individual employee under their responsibility. The performance indicators vary across public organisations depending on the desired core competencies among the staff members. Criticisms, complaints, and cynical references about the implementation of PA are common among employees. The employees' perceptions of the PA system and decision-making process will influence their level of job satisfaction (Ahmad, 2019, 2016; DeNisi, Cafferty \& Meglino, 1988). This in turn, lead to workers' unions and non-governmental organisations expressing their concerns of the rating system which impact on the PA process and the decisions arrived at. In this study, the PA system is viewed strategically as it is not only reflected in the strengths and weaknesses but also in the opportunities and threats which can also be used to enhance or reduce them accordingly.

PA is a subject of great interest to employees as the decisions made in relation to their work performance will affect their income, motivation, commitment and more severely, may even determine the organisation's survival (Ahmad, 2019; Ahmad, 2016; Armstrong, 1998; Armstrong \& Baron, 1999). However, many factors contribute to the employees' perceptions on the effectiveness of a PA system, and a more comprehensive review of the PA process is 
needed to determine the related issues in developing a more favourable appraisal system. Thus, this study does not only focus on the strengths and weaknesses of the PA system in use, as is commonly done but also looks at the opportunities and threats which can provide value- added information to the organisation in reducing the negative perceptions of their employees which in turn can affect job satisfaction. In short, this study hopes to provide evidence to expand the understanding and a better explanation of the PA system currently in use to further improve the system and hopefully increased level of job satisfaction among the employees.

Past research on PA shows vast perspectives. Brown et al., (2019), DeNisi and Murphy (2017), Yazid et al., (2017) studied the relationship between PA and demographic factors, multi-generations and turn over intentions. Elsewhere, DeNisi et al., (2017), Khoreca and Tenhiala (2016),Lin and Kellough (2019) and Thorton et al. (2019) in their studies found that PA is potentially influenced by other demographic factors such as gender, age and discrimination factors at work. Previous research conducted on PA have also indicated the relationship between the system design, managerial practices and system support were significantly and positively related to the effectiveness of the system (Leong, 2015; Linda, 2015; Longenecker,1992; Scott, 2001;). These findings also suggest that the way the organisation manages and implements the PA system influences the employees' reactions towards the system and the organisation at large. In addition, weaknesses in the PA system such as the employees finding it difficult to understand the instructions in the appraisal form as not user-friendly (Sime, 1999; Scott, 2001) also affect their perceptions. On a different level, a study by Longenecker (1992) points at the appraising managers who show that $83 \%$ is meant to fail without clear established performance criteria and ineffective rating instrument. Ironically the same managers lament the appraisals they receive often do not accurately represent their abilities and performance (Gioia \& Longenecker, 1994). Clearly, past research indicates the concern on the efficiency and effectiveness of the PA system and the decision making process involved. Thus, it is timely to review the PA system in public organisations as a properly executed PA process will surely serve both evaluators and those evaluated well.

In practical terms, an effective and efficient PA system will reduce criticism and concern among employees as well as workers' unions and associations. At the same time, identifying the strengths, weaknesses, opportunities and threats will provide interested parties with a more reliable and comprehensive picture of what the PA system entails from the employees' perspectives so that further concrete action can be taken to improve the system by the organisational stakeholders; internal and external. Based on the rationale of conducting the current study in terms of knowledge gaps, empirical gaps and practical gaps, the areas under research for the current study are indicated in the framework below:

Figure 1.1 Conceptual Framework

\section{Performance Appraisal}

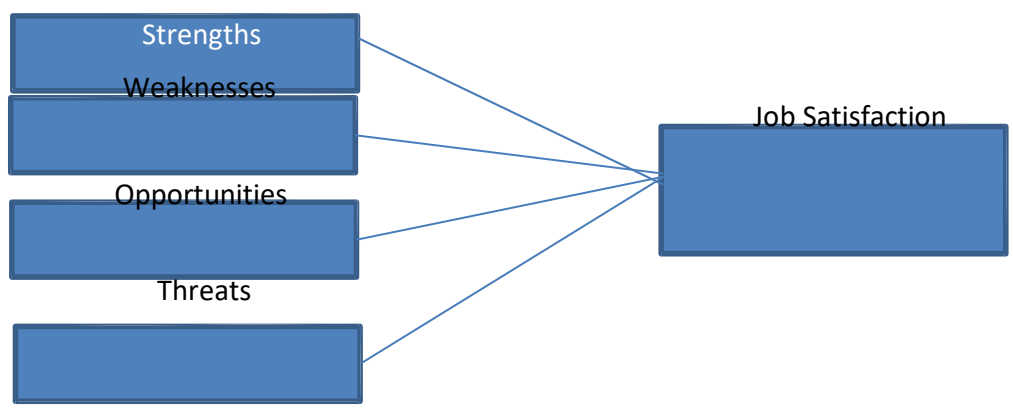




\section{MATERIALS AND METHODS}

Quantitative methodology was applied in this study as it has the capability to measure the relationship between all related variables in this study. Simple random sampling technique was used to collect the data among the employees in the selected public institution of higher learning in Sarawak. In this study, the research design was a combination of correlational and survey types of research. An adapted questionnaire consisting of 7 sections: the respondents' demographics, the strengths, weaknesses, opportunities and threats (SWOT) of the current performance appraisal system, job satisfaction and retention was utilized as the research instrument in obtaining quantitative data. The SWOT aspects were sourced and adapted from previous literature based on research findings on the effectiveness of performance appraisal which is also a common topic in textbooks on human resource management or human resource development and specifically performance management, to name a few: Werner and DeSimone 6th ed, (2012), Ahmad (2016, 2019), Amstrong (1998, 2006) and Armstrong and Taylor, (2017). For job satisfaction, the items were also adapted from the established Generic Job Satisfaction scale of Macdonald and Maclntyre (1997).

The target population was drawn from the academicians currently employed in two public institutions of higher learning. A pilot study was conducted to test the survey instrument in one of the public institutions. The results of the pilot study shows that the validity and reliability aspects were taken care of systematically, with a Cronbach Alpha value of 0.70 and above. Various comments provided by the respondents in the pilot study were taken into account to improve the instrument in terms of the order of the items as well as the terminology to avoid misinterpretation of the focus in the survey.

In the actual study conducted in the second public institution of higher learning, the sample size was determined by using $\mathrm{G}^{*}$ Power analysis. The results suggested that a minimum of 138 respondents were sufficient for data analysis in the actual study. Nonetheless, a total of 221 respondents, more than 50 percent of the population, participated in the data collection. Normality tests using skewness and kurtosis were performed and results met the normality requirements. Therefore, Pearson Correlation and Multiple Regression analysis were conducted to analyze the relationship between SWOT and job satisfaction.

\section{RESULTS AND DISCUSSION}

This research attempts to determine the influence of performance appraisal SWOT as antecedents of job satisfaction among employees in a selected public institution of higher learning in Sarawak, East Malaysia. Pearson correlation was used to test the following hypothesis and results are as in Table 1.

\section{Hal: Strength, Weakness, Opportunity and Threat have a significant relationship with Job} Satisfaction.

Table 1: Result of Pearson Correlation between Strength, weakness, opportunity and threat and Job Satisfaction 


\begin{tabular}{lll}
\hline Variables & $\boldsymbol{r}$ & $\boldsymbol{p}$ \\
\hline Strength & .463 (Moderate) & .000 \\
Weakness & $.357($ Weak $)$ & .000 \\
Opportunity & $.308($ Weak) & .000 \\
Threat & $.357($ Weak $)$ & .000 \\
\hline
\end{tabular}

Since $p<0.05$, Ha1 is accepted. Therefore, it can be indicated that there is a significant relationship between strength, weakness, opportunity and threat and job Satisfaction.

Table 2: Result of Multiple Linear Regression (Stepwise)

\begin{tabular}{llllll}
\hline Variables & B & Std. Error & Beta $(\boldsymbol{\beta})$ & $\boldsymbol{t}$ & $\boldsymbol{p}$ \\
\hline Strength & .347 & .069 & .338 & 5.045 & .000 \\
Weakness & .177 & .038 & .271 & 4.607 & .000 \\
Opportunity & .121 & .061 & .129 & 1.979 & .049
\end{tabular}

$$
R=.541, R^{2}=.293, \text { Adj. } R^{2}=.283 ; F=29.94, p=.000<0.05
$$

The result shows that there are three predictors of Job Satisfaction that are significant with a good fit of $F(3,217)=29.94, p=0.000$. Results revealed that $R^{2}=0.293$ indicated that $29.3 \%$ of the variation job satisfaction is explained by strength $(\beta=.347)$, weakness $(\beta=.177)$, and opportunities $(\beta=.121)$. It can be indicated that strength is the most dominant predictor that contributed to job satisfaction.

This study found that strengths, weaknesses, opportunities and threats of the practice of PA have a significant effect on job satisfaction. The strengths have the strongest relation and it is not surprising as almost everybody within the organisation will certainly be happy about this aspect. The strength aspect is in line with the theory of expectation which gives more emphasis on the expected good outcomes of the system which form the perspectives of the employees. Logically, all employees will like all aspects of the system which give benefits to them. Likewise, they will dislike all aspects that will put them on the losing end. This concern was highlighted by DeNisi et. al (1991) and in line with the research findings from a study conducted by Ahmad (2003) on the Malaysian Public Service.

Thus, the main results revealed that performance appraisal using SWOT has an impact on job satisfaction. These findings are in line with those found in literature such as the studies in which Kompkotter (2017) and Prasad (2015) reported similar findings indicating that performance appraisals have a positive and highly significant effect on job satisfaction.

The results of the current study also agree with the results reported by Agyare et al., (2016) which indicates that a positive relationship exists between employees' job satisfaction and the factors: fairness of an appraisal system, rewards, clarity of roles and the provision of feedback about employees' performance.

In addition, the current results also found that the strength domain of performance appraisal evaluation is the dominant factor that contributes to Job satisfaction. The results appear to be 
compatible with our expectations whereby strength of performance appraisal that involve clear objectives, receiving strong support from top management and feedback on PA might help to improve job performance.

\section{CONCLUSION}

The findings indicate that there is a positive significant relationship between the PA system (strengths, weaknesses, opportunities and threats) and job satisfaction, based on the respondents' perceptions. The strength of the relationship is weak and moderate. The findings also show that the strengths of the PA system are the most dominant predictor of job satisfaction. This implies that it is essential to ensure the strengths of the current system are maintained and sustained continuously.

To expand this research study, the sample size can be extended to include other public institutions of higher learning in Malaysia in order to get a comprehensive review of organisations using similar performance appraisal indicators. The methodology can also include qualitative approach such as focus group interviews to clarify and verify the findings from the quantitative study. In doing so, the validity and reliability of the findings will be enhanced. It is also our hope that the data from the SWOT analysis can be used to establish an index to determine the status of the PA system in use as a basis for undertaking continuous improvements to the system.

\section{ACKNOWLEDGEMENT}

Our appreciation to all those involved directly and indirectly in the conduct of this study: the management of our institution for their support and sponsorship,

the management of our target institutions for their co-operation,

the respondents for their time and effort and lastly,

all team members for their commitment and fellowship.

\section{REFERENCES}

Agyare, R., Yuhui, G., Mensah, L., Aidoo, Z., \& Opoku Ansah, I. (2016). The Impacts of Performance Appraisal on Employees' Job Satisfaction and Organizational Commitment: A Case of Microfinance Institutions in Ghana. International Journal of Business and Management, 11(9), 281. https://doi.org/10.5539/ijbm.v11n9p281

Ahmad R., (2016). Performance appraisal system for organisation. Kota Samarahan, UNIMAS Publisher.

Ahmad, R., (2019). Performance appraisal: The past, present and the way forward, Kota Samarahan, UNIMAS Publisher.

Anitha, R.V.M and Pavithra, P. (2018). Impact of Job Satisfaction on Employee Retention of IT Professionals. International Journal of Trend in Scientific Research and Development, 2(3), $382-385$

Armstrong, M., (1998). Managing People: A practical guide for line managers. London: Kogan Page Limited. 
Armstrong, M. \& Baron, A. (1998). Performance management: The new reality. London: Institute of Personnel and Development.

Armstrong, M. (2006). A Handbook of Human Resource Management Practice. $10^{\text {th }}$ ed. London: Kogan Page Publishers.

Armstrong, M. \& Taylor, S. (2017). London: Kogan Page Publishers.

Appelbaum, H., Roy, \&Gilliland, T. (2011) Globalization of performance appraisals: theory and applications. Management Decision, 49(4), 570 - 585.

Brown, T. C., O’Kane, P., Mazumdar, B., \& McCracken, M., (2019). Performance management: A scoping review of the literature and a agenda for future research. Human Resource Developmental Review, 18(1), 47-82.

Chen, J. \& Eldridge, D. (2012). Are standardized performance appraisal practices really preferred? A case study in China. Chinese Management Studies, 4(3), 244 - 257.

Daosis, L. E. (2012). Performance Appraisal System: It's Implication To Employee Performance. International Journal of Economics and Management Sciences, 2(3), 55 -62 .

DeNisi, A.S, Cafferty, T. \& Meglino, B. (1988). A cognitive view of performance appraisal process: evidence from the field. Journal of Applied Psychology, 33, 360 - 396.

DeNIsi, A.S., \& Murphy, K.R., (2017). Performance appraisal and performance management:100 years of progress. Journal of Applied Psychology, 102(3), 421 - 433.

Idowu, Ayomikun (2017). Effectiveness of Performance Appraisal System and its Effect on Employee Motivation. Nile Journal of Business and Economics. Researchgate. http://journal.nileuniversity.edu.ng/index.php/NileJBE

Kampkötter, P. (2017). Performance appraisals and job satisfaction. International Journal of Human Resource Management, 28(5), 750-774.

https://doi.org/10.1080/09585192.2015.1109538

Khoreva, V., \& Tenhiala, A., (2016). Gender differences in reactions to injustice. Journal of Management Psychology, 48(2), 179 - 202.

Lin, Y.C., \& Kellough, J.E., (2019). Performance appraisal problem in the Public Sector: Examining supervisor's perception. Public Personel Management, 32(2),

Macdonald, S. \& Maclntyre, P. (1997). The Generic Job Satisfaction Scale. Employee Assistance Quarterly, 13:2, 1-16, DOI: 10.1300/J022v13n02_01

Maley, J. (2013). Hybrid purposes of performance appraisal in a crisis. Journal of Management Development, 30(10), 1093 - 1112. 
Prasad, P. (2015). Performance Appraisal: An Empirical Study to understand Job Satisfaction and Motivation of personnel through the system topics. International Journal of Engineering and Applied Sciences (IJEAS), 2(4), 118-125. www.ijeas.org

SHRM (2016). Performance Management that makes a difference: an evidencebased approach.

Thorston, G.C., Rupp, D.E., Gibsons, A.M., \& Vanhove, A.J., (2019). Same-gender and same-race-bias in assessment center ratings: A rating error approach to understanding subgroup differences. International Journal of Selection and Assessment, 27(1), 54 71.

Tuytens, M. \& Devos, G. (2012). Importance of system and leadership in performance appraisal. Personnel Review, 41(6), 756 - 776.

Werner, J.M \& DeSimone, R.L. $6^{\text {th }}$ ed (2012). Human Resource Development. USA: SouthWestern CENGAGE Learning.

Yazid, Z., Atikah, N., \& Baharom, A.R., (2017). Konflik dalam proses penilaian prestasi dalam organisasi (Conflict during performance appraisal process in an organisation). Jurnal Pengurusan, 49, 41 - 52. 